\title{
Student Protests and Organised Labour: Developing a Research Agenda for Mobilisation in Late-Neoliberalism ${ }^{1}$
}

\author{
Draft \\ April 30, 2019
}

\author{
Didem Türkoğlu \\ University of North Carolina at Chapel Hill, Department of Sociology
}

Students have a long history of protesting the introduction or rise of tuition fees. However, political parties do not often endorse their demands. Even the centre-left, which is known for its redistributive policies, does not necessarily ally itself with the student opposition to fees. In this article, I focus on the impact of social movementorganised labour alliances on the opposition of political parties to government policy. I argue that such alliances have a unique impact on centre-left parties, especially in relation to non-labour issues. I present two examples of this alliance, emerging from the quite different political contexts of Germany and Turkey. In Germany, student movements failed to block the introduction of tuition fees in 2006. However, in 2008-2011, after students established a deeper alliance with organised labour, tuition fees were scrapped. In Turkey, student movements had been protesting tuition fees for a quarter of a century before an alliance with labour gained the support of social democrats in 2011. These case studies suggest that labour-movement alliances are effective in shifting social democratic politics in higher education policy because of the labour's experience and know-how in alliance building with centre-left parties and the student mobilization's potential to make tuition fees an electoral issue cross-cutting party allegiances. This finding suggest that scholars need to take the degree of engagement in opposition alliances into account, in addition to union density, in order to more accurately measure the political power of the organised labour. This point has implications for analysing a variety of policy outcomes in policy areas exposed to permanent austerity measures.

${ }^{1}$ Forthcoming in Current Sociology (2019). I thank Charles Kurzman and Neal Caren for their advice and support in this project. I also would like to thank Andy Andrews, the participants of UNC Culture \& Politics workshop and COSMOS conference for their valuable feedback. I am grateful to Lorenzo Cini and Cesar Guzman-Concha for putting together the special issue idea, Johanna Lauber, Sabrina Zajak, Thomas Sablowski, Felix Silomon-Pflug, Ismet Akça, Aslı Odman, Berker Akdevelioğlu, and Binnaz Toprak for their help in establishing contact with my interviewees and accessing data. My thanks also go to my office mates Holly Straut- Eppsteiner and Karam Hwang who provided solidarity at different stages of this project by their presence, Murat Demiroğlu for his encouragement and support, my interviewees who generously shared their time with me, anonymous reviewers and the editors of Current Sociology Karim Murji and Sarah Neal for their suggestions.

This research was partially supported by the European Union/ Center for European Studies at UNC-Chapel Hill Summer Research Fellowship and the UNC Graduate School Graduate Student Transportation Award. 


\section{Introduction}

Faced with the challenges of "permanent austerity" (Pierson 2001), a turn to social movement unionism and transnational alliances signalled the revitalisation of labour activism since the 1990s (Almeida, 2006; Dixon and Martin, 2012; Turner and Hurd, 2001; Voss and Sherman, 2000; Zajak, 2013). The impact of this social movement like mobilisation in labour-related issues showed that social movement unionism or alliances with community organisations could be a way to regain some of the voice organised labour has lost in industrial relations (Grote and Wagemann, 2018; Hess, 2014;

Obach, 2004; Tattersal, 2010). How about social and economic rights that were also reshaped by neoliberal policymaking, besides labour? How effective are the alliances between labour unions and social movement organisations regarding the issues outside labour's purview? Can they influence political party positions?

In this article, I offer a critical research agenda for investigating the dynamics of trade union- social movement alliances under permanent austerity by using the interaction between unions and student mobilisation against tuition fee hikes as a case study. While scholars do study social movement unionism under neoliberalism, with very few exceptions, these works focus on social movement type activism in labour-related issues that focus on the interactions in the workplace or the communities where the workers live (see Zajak et al., 2018 and Grote and Wagemann 2018 for theoretical exceptions). However, social movement unionism is integral to alliance building with social movements. More importantly, these alliances can be used as leverage to shift political party positions in policy areas beyond industrial relations. 
I argue that organised labour - social movement alliances have a unique advantage in influencing social democratic parties. With an alliance, trade unions and social movement organisations can combine different brokerage networks. Unions might be able to transfer some of the institutional and structural advantages they acquired in the field of labour policy even when they are mobilised as outsiders in a different policy area. Social movements, on the other hand, provide opportunities for cross-class mobilisation, which become quite important on the eve of elections. This combination of unionmovement alliance might increase political pressure on the parties while providing unique opportunities for them to consolidate their base. Because of this role, social movement - organised labour alliances might contribute to the realignment of centre-left parties away from neoliberal policy commitments and towards their more traditional redistributive policies.

Previous scholarship has theorised the interactions of movements with political parties and the interaction of the organised labour with the centre-left parties separately. I propose to study this interaction with all three actors. I present two examples of this alliance, in two different political contexts. In Germany, student movements failed to block the introduction of tuition fees in 2006 in half of the country, but reversed tuition fee policies in 2008-2011 after building a deeper alliance with organised labour. In Turkey, student movements had been protesting tuition fee increases for quarter of a century before an alliance with labour gained the support of the social democrats in 2011 . These cases suggest that union-movement alliances are effective in shifting social democratic politics.

\section{Theoretical Framework}


Previous scholarship analysed trade union-political party and social movementpolitical party interactions separately, but an analysis of the impact of movement-labour alliances on the political parties necessitates the analysis of a triadic relationship. Scholars who work on trade union-party relations focus on the implications of the decline of union strength. Scholars in social movement studies analyse the movements' involvement in the electoral politics in relation to political opportunity structures and movement tactics. Building on the findings of these literatures, I will provide an alliancefocused explanation to highlight the interactions between movements, unions, and parties as three corners of oppositional politics.

Union-party relations. The affinity between the trade unions and the centre-left parties has been studied widely, in part due to the strength of this relationship between the 1950s and the 1980s. Scholars argue that with the advent of neoliberal policies and the decline of union strength, this affinity has, to a degree, declined. They explain the weakening of this relationship by structural factors, such as the relative power of the centre-left in a given polity, union density and the type of the welfare state regime (Huber, Ragin \&Stephens, 1993; Graeme, 2004). Nevertheless, when a social democratic government represents labour interests, scholars expect to see a decline in contentious action, as labour conflict can be resolved at the parliamentary level through policy negotiations (Korpi \& Shalev, 1980; Ahlquist, 2010).

However, scholars now suggest that the trade unions have lost their position as partners in the social contract between the state, business and society at large. They have become an interest group just like any other (Culpepper \& Regan, 2014; Durazzi, Fleckenstein \& Lee, 2018). As unions lose their seat at the negotiating table, they might 
emphasise solidarity for all and engage in more contentions actions such as strikes (Upchurch \& Taylor, 2016), shifting towards 'radical political unionism' (Gordon \& Upchurch, 2012; Connolly \& Darlington, 2012).

Movement-party relations. Until relatively recently, social movements and institutionalised politics have been seen as separate paths of opposition (Jenkins \& Klandermans, 1995). Based on Charles Tilly's (1978) distinction between challengers and polity members, scholars generally endorsed Gamson's (1990) definition of social movements as outsiders to institutional politics. Gradually, however, social movements scholarship began to highlight how social movement activity and institutionalised politics are related (Van Dyke, 2003; Goldstone, 2003). Scholars argued that using contentious action in combination with assertive/electoral action is critical, especially when movements face unfavourable political contexts (Kriesi, 2004; Tarrow, 2011). Political mediation theory, for example, contends that the consequences of mobilisation and even the strategies used by social movements depend on the specific political context and the type of influence that is being sought (Amenta et al., 2005).

Social movements might endorse new forms of collective action that serve to influence parties and cause realignments within them, but they may also join existing coalitions or turn into parties themselves (McAdam \& Tarrow, 2010). However, not all movements engage in electoral politics effectively due to the lack of organisational resources, their perception of opportunity and threat, or the short duration of protest cycles (Blee \&Currier, 2006; Obach, 2010; Tarrow, 2011). Student movements are one such case, where the turnover and the lack of organisational resources to engage with 
electoral politics places activists at a disadvantage. Within this context, alliances become vital.

Union- movement relations. Until recently, trade unions and social movements have also been analysed separately because of their organisational differences (Zajak et al., 2018; (Diani, 2018). Scholarly interest in social movements and trade union alliances peaked within the context of union revitalisation in industrialised democracies (Robinson, 2000; Voss and Shearman, 2000). Scholars argued that, as the power of trade unions declined, unions attempted to compensate for their membership losses by building alliances with community organisations (Fransosi, 2006; Tattersall, 2010; Heery, Williams \&Abbott, 2012).

Social movement scholars also offer some insights into the conditions under which coalitions of movements might emerge (Van Dyke \& McCammon, 2010; Loschi, 2018; Lee, 2011), which can be applied to analyse union-movement alliances. Processes of brokerage, ideological positioning, the perception of similar threats, social networks, or strategic considerations can all account for increased cooperation (Beamish \& Luebbers, 2009; Dixon \& Martin, 2012; Reese et al., 2010; Tattersall, 2003; Van Dyke, Dixon \&Carlon 2007; Corrigall-Brown \& Meyer, 2010; Cobble 2004; Vicari 2014; Dixon, Danaher \& Kail, 2013; Zajak et al, 2018). On the other hand, disagreements over tactics, a lack of resources or the segmentation of policy areas in ways that hinder comprehensive action might deter such coalitions (Mische, 2008; Obach, 2004; Obach, 2010; Rose, 2000). Some of these disagreements can be overcome more easily once trade unions endorse social movement unionism. 
Social movement unionism refers to a trade union's participation in and organisation of social movement-type protests, often centred on broader social justice issues that require alliance building (Clawson, 2008). Involvement in a broader social movement can induce social change in favour of labour, while investing in social movement unionism can support the emergence of the next wave of the social movement (Turner \& Hurd, 2001). Unfortunately, most scholarship on social movement unionism analyses the extent to which unions have increased their capacity to influence labour policy, rather than the broader impact this might have in the political arena (Grote \& Wagemann, 2018).

Movement- union-party relations. The contribution of this article is to approach alliance building by considering all three actors that join forces in opposition to policy beyond labour-related issues. I analyse how a social movement - labour alliance on a non-labour issue affects the positions of political parties.

I argue that student groups and the organised labour pool together different networks and resources that they have developed through past engagement, which gives a unique edge to the alliance. Scholarship on social movements emphasises the importance of social capital and the structural position of the movement actors (Diani, 1997; Voss \&Sherman, 2000). Brokerage networks and processes differ based on whether the broker is bringing together previously disconnected groups or not (Krinsky \& Crosley, 2014). As organised labour moved into the realm of social movements by adopting some of their tactics it has also established working relations with them. This provides the unions with a unique brokerage position based on their past engagement with the centre-left parties. Students, on the other hand, are in a position to mobilise a new constituency for centre- 
left parties, as they can make connections in both working and middle-class bases through their networks of student groups (Crosley \& Ibrahim, 2012). In the case of tuition policy, which will be examined more extensively below, student groups can use their power of disruption while unions provide know-how on pressuring political parties through assertive and contentious action.

\section{Data and Methods}

A comparison of student-labour alliances in Germany and Turkey provides a unique opportunity to evaluate the alliance-building process in two radically different union structures and political contexts. The process in Germany demonstrates how a trade union, which plays an insider role in a corporatist framework, helps a social movement group sustain and increase pressure on the centre left. In contrast, in Turkey, where the influence of the leftist unions is far more limited and the political structure is quite closed to movement pressures, unions have supported student activism in the absence of nationally-organised student unions. Thus, despite the differing political contexts, similarities in movement-labour alliances in Germany and Turkey can be observed in terms of how they pool resources and their impact on centre-left parties in a non-labour policy area even if union membership is in decline.

I conducted fieldwork in Germany and Turkey between 2013-2016 and interviewed 51 people including policy experts, politicians, student activists, activist faculty, and union members (see table 2).

- Table 2 here -

I also gained access to publications from the private and public archives of social movement organisations and participants. These include Eğitim-Sen and Öğrenci 
Kollektifleri publications against tuition fee increases in Turkey and a private collection of student movement publications that specifically targeted proposals to introduce tuition fees between 2003-2007 in Frankfurt, Germany.

Data analysis involved triangulating data with media coverage. I selected one major newspaper in each country and systematically analysed the coverage of tuition fees debates. I then built a database of newspaper articles for every relevant wave of protest reported in Frankfurter Allgemeine Zeitung (FAZ) in Germany and Hürriyet in Turkey between 2000-2015. Due to the polarisation of the media environment in Turkey I also added reports from Cumhuriyet to my analyses to reflect mainstream media coverage more comprehensively.

This article applies a mixed-methods research design. I combine quantitative and qualitative analyses of media coverage with in-depth case study comparisons and the analyses of interviews. Together, these approaches allow me to trace alliance-building process in different political contexts. Process tracing is a comparative-historical method that aims to explore mechanisms and sequences through in-depth case studies (Lange, 2012). It focuses on the comparison of mechanisms between explanatory variables and outcomes. The comparison of alliance building, in the absence of the full support of unions and with union involvement, will demonstrate the impact of the networks organised labour and social movements have created. Case studies provide insight into how this mechanism of alliance building has occurred in a similar manner, in two different political contexts with strikingly dissimilar state structures and degrees of political openness and where student unions function in contrasting ways (Crosley \& Ibrahim, 2012). 


\section{Student- labour alliances}

\section{Germany}

The position of German unions is among the strongest in Europe, due to their structural position as well as the corporatist nature of industrial relations in Germany. They have nevertheless faced a decline in membership and a significant decrease in their political power since the1990s (Turner, 2009). Student-labour alliances were not historically common. Even in the late 1960s and early 1970s, at a time when left-wing students and organised labour had closer relationships in Europe, student movements and labour movements in West Germany remained separate (Turner, 2009). Organised labour did pursue social movement tactics at the time, but focused on institutional consolidation to achieve stronger unions and works council rights.

Social movement unionism became a viable option in Germany in the mid-2000s. Scholars consider the institutional embeddedness of German unions as an outlier in Europe, but in the past decades, unions have started to lose their institutional standing. Consequently, trade unions have increasingly endorsed contention and cooperation simultaneously (Greer, 2008). The diffusion of social movement unionism tactics has led IG Metall in Germany to adopt some of the tactics developed by the Service Employees International Union (SEIU) in the US (Nicklich \& Helfen, 2018). Social movements have, to a degree, become strategic partners that help to compensate the unions' loss of institutional power, especially in the case of the German Trade Union Confederation, Deutsche Gewerkschaftsbund (DGB) (Dörre \& Nachwey, 2009). The DGB's active participation marks an interesting deviation from the German trade union tradition that is based on an understanding of social partnership (Baccaro et al., 2003) rather than social 
movement unionism. The Education and Science Workers' Union, Gewerkschaft Erziehung und Wissenschaft (GEW) has a distinct place under the broader umbrella of the DGB. It is dominated by primary and secondary school teachers and experienced a decline in the mid-2000s (Behrens \& Pekarek, 2016). At the turn of the $21^{\text {st }}$ century, the DGB started to experiment with building alliances with the environmental and antifascist movements, but this remained a rare occurrence, both within the DGB and among the unions in general (Behrens et al., 2003). Alliances with students became an option as the student protests arose against the introduction of tuition fees.

Until 2005, tuition fees were under the jurisdiction of the federal government and tuition remained free. In 2005, the centre-right CDU brought the issue to the constitutional court and obtained a ruling in favour of state rights. Once states had the right to instate tuition fees, the states that were ruled by conservative governments announced the introduction of tuition fees starting from 2006-2007. The table below shows the dates of the introduction and abolition of tuition fees as well as the parties in power in the states that introduced tuition fees. Both the CDU (Christian Democrats) and the FDP (Centrist liberals) favoured tuition fees in Germany. Hesse was the first state that repealed the tuition fees; therefore, I will focus on the alliance building processes in Hesse.

- Table 1 here-

The GEW opposed tuition fees from the very start (Keller, 2002). However, until 2005-2006, the umbrella confederation, DGB, was not as actively involved. After publicly announcing their opposition to the introduction of tuition fees, the GEW and DGB remained largely in the background until the terms of the legislation started to be 
negotiated in the state parliaments. In Hesse, student protesters, student movement organizations, and political parties led the tuition fees debate (FAZ, 2006b, 2006c). The DGB raised concerns that the introduction of tuition fees would increase the pressure on vocational training (FAZ,2006a), but its protest efforts focused on the general public budget cuts rather than the higher education-specific concerns surrounding tuition fees (Welsh, 2009).

The DGB coordinated simultaneous demonstrations against welfare state reforms, one of which took place in Frankfurt, Hesse. In Frankfurt, autonomous leftist groups, Antifa Frankfurt, and the student union AStA (Allgemeiner Studierendenausschuss - The General Students' Committee) joined the protests. However, rather than marching under the same banner, students used their own slogans and demonstration routine to highlight their opposition to tuition fees (FAZ, 2006d). This protest event is one of the instances that demonstrates the affinity between the DGB and the students, but the separate demonstration routines also show that there was no unified alliance.

Tuition policy continued to be one of the priority issues on the agenda on the eve of the 2008 state-level elections. Student unions and the youth branches of the centre-left parties tried to lobby the politicians. AStA has branches on most university campuses and has been one of the predominant student organisations in the coordination of political activities against the introduction of tuition fees. However, it faced a challenge in its lobbying efforts. At the national level, the SPD (social democrats), the Greens, and the Left Party (die Linke) were all opposed to the introduction of tuition fees. However, at the local level, both the SPD and the Greens have indicated that they could sacrifice their position and live with the tuition fees in the case of a coalition government with the CDU 
or FDP. In Wiesbaden, Hesse, the CDU, the FDP, and the Greens agreed to commission a report on tuition fees to ensure the city would remain attractive to students, while only the SPD and the Left Party wanted to pass a resolution in support of the student protests (FAZ, 2006e). This was one of the instances that signalled that the Greens might join CDU and FDP in local tuition policy. In the meantime, the SPD in Hesse started to explore coalition options with the CDU and FDP in 2006, receiving sharp criticism from the youth branch of SPD (the Jusos) because of the parties' 'elitist and anti-social education policy' (FAZ, 2006f). Even the student members of the party were concerned that the SPD might make concessions on its opposition to tuition fees in the event of a coalition.

By the end of 2006, it looked entirely possible that tuition fees would remain in place. However, the second wave of protests started, this time with more support from the unions. This wave of mobilisation combined protests with assertive action, targeting the opposition parties and the legislature specifically. One of the former student activists I interviewed explains:

[In addition to student groups] some branches of the education unions, some branches of the general union DGB-Deutsche Gewerkschaftsbund [were present.] They were necessary for public support, information distribution and financial support. The movement at the local level didn't break down thanks to their support. (Jan, 2014)

In this second wave, in addition to demonstrations and traffic blockades, the mobilised groups initiated a petition campaign using plebiscitary law-making as a tactic. On the students' initiative, a 'constitutional complaint from below' was filed at the state court. (FAZ, 2007a). The state court has jurisdiction over matters that concern fundamental human rights and constitutional disputes. Hesse law states that in order to bring a lawsuit before the state court, one percent of all eligible voters (approximately 4,3 
million persons) must join the initiative. By mid-May, the petition campaign had reached 40,000 signatures (FAZ, 2007b). However, with ten days remaining to the deadline, the initiative was still 1000 signatures short. The DGB stepped in with a public endorsement to make one final push $(\mathrm{FAZ}, 2007 \mathrm{c})$. With this final push, the initiative was able to collect 62,500 signatures, well above the required 43,000, by the end of May (FAZ, 2007d). These signatures put a plebiscite-like pressure on the government on the eve of the elections. The Greens and the SPD supported the initiative, which strengthened their anti-tuition fee position before the elections.

As the state court's decision was scheduled for after the elections, the DGB increased the pressure on the state government to hasten the court process (FAZ, 2008a). The GEW organised a press conference together with the student representatives and uncharacteristically made an endorsement: 'The left-wing parties have promised to take back the tuition fees if they win, so we will take their word for it' (FAZ, 2008b). Over all, during the second wave of protests, the unions' financial and legal support enabled the tuition fees to remain on the agenda at multiple institutional levels, and enabled sustained involvement of the opposition parties in the triadic alliance relationship in Hesse.

During the 2008 elections, the CDU suffered serious losses, while the SPD picked up many seats. It looked like the SPD, the Greens, and the Left would have enough votes to change tuition policy at the state level. However, the coalition negotiations among the parties failed while a grand coalition was not possible because of the polarisation of the CDU and SPD. Consequently, a second election was called. As the student protests continued, the CDU abolished tuition fees in order to avoid another electoral failure, and promised not to reintroduce them if it won the elections in 2009 (FAZ, 2008c). 
- Figure 1 here-

The figure above summarises the Frankfurter Allgemeine Zeitung's coverage of the tuition debate. News on student collective action against tuition fees peaked in 2006, while union action (DGB and GEW combined) remained somewhat in the background at the same time. Despite the intensity of student collective action, in the absence of a stronger alliance, tuition fees remained in effect. During the second wave, the opposition to tuition fees was at its strongest in 2008 and 2009 with union and political party endorsements. Consequently, the CDU was forced to reverse its position to remain in government. The unions' engagement with assertive action and electoral politics during the second wave of mobilisation (2007-2008) were the reasons behind the increased coverage of the unions on tuition policy. Social movement scholars who study media coverage find that elections usually dwarf the coverage of social movement activities (Amenta et al, 2017). This might partially explain the decrease in the coverage of student collective action, but the increase in the coverage of union activities becomes more significant under these circumstances.

The reversal of Hesse's tuition policy created a domino effect, keeping the topic on the electoral agenda in the rest of the states that had introduced tuition fees. Another student activist I interviewed explained the effect as follows:

What happened in Hesse was amazing! We were in touch with them but we were losing steam here [Cologne, North Rhine-Westphalia]. It looked like we had to go back to studying. And then news came from Hesse and we were on the streets again. (Klaus, 2016)

By the end of 2013, German public higher education was tuition-free once again. The parties that had introduced tuition fees either reversed their position or lost the elections (see table 1). Trade unions played a key brokerage role in this process: firstly, by 
supporting the students' assertive action by collecting the additional petition signatures needed, and secondly, by using their insider knowledge and engaging in electoral politics. This strengthened the resolve of the SPD and the Greens to continue to push for free tuition at a time when tuitions could have become a bargaining chip in coalition talks with the centre-right.

\section{Turkey}

The affinity between student protests and union activism goes back to the 1960s; a period marked by the politicization and the fragmentation of the trade unions. While pro-government unions pursued "unionism above politics," others opted for "radical unionism" by organizing protests, strikes, and building alliances with left-wing political parties (Doğan, 2018). This was also the time of the rising student movements both on the left and the right (Neyzi, 2001). Students protested alongside unions for the expansion of welfare state rights and better working conditions. In 1980, a coup d'état put a halt to the student and trade union movements and banned the unions for a decade.

In 1990, the right to unionize was formally recognized in accordance with the international agreements but national law was still ambiguous until 1995. In 1995, two teachers' unions (established in 1990) merged and formed Eğitim -Sen, the Education and Science Workers' Union. It became one of the leading unions in the public employees sector, organised under the umbrella of KESK (Confederation of Public Employees Trade Unions) (Üzüm, 2011), which worked closely with DİSK (Revolutionary Confederation of Trade Unions) that mostly represented blue-collar workers. In 2001, Eğitim-Sen endorsed a higher education mission and started to organise in universities (Eğitim-Sen, 2018). 
Tuitions were introduced in all public universities in 1984, at a time when all opposition parties of the previous decade were banned, student leaders were imprisoned, and trade unions were closed (İnal and Akkaymak, 2012). In the mid-1990s, the student movement revived when the government announced a $350 \%$ tuition fee hike. There were street protests and campus occupations. Ankara and Istanbul became the focus of student protests. In the face of increased repression of the protests, the two newly established unions Eğitim-Sen and Harb-iş (Union of Defence Industry and Allied Workers) sent representatives to the demonstrations to show symbolic support (Cumhuriyet, 1995b). However, the unions themselves were fighting for their survival at the time because the government questioned the public employees' right to unionize. As student protests continued into 1996, the public employees unions were focused on organizing demonstrations demanding the right to collective bargaining and strike (Cumhuriyet, 1996c). Both the student movement and the labour movement remained sympathetic to each other's cause but followed their separate paths.

Students engaged in assertive action, but in the absence of a broad-based alliance, they were not able to put pressure on the centre-left. They petitioned the Grand National Assembly with 350.000 signatures (Cumhuriyet, 1995a) and sneaked in banners during its proceedings to demand free higher education. Their protest in the parliament was illegal at the time, and the activists were sentenced under terrorism charges (Cumhuriyet, 1996b). Social democrats supported the students' right to protest but did not endorse free higher education (Cumhuriyet, 1996c). The student movement slowly dispersed within the rising democracy movement in the late 1990s. 
Tuition fee increases led to protests once again in 2008. This time, the alliance structure of the opposition was quite different, both the blue collar and white collar leftwing unions supported the student movement. The union arena was split along ideological lines with pro-AKP(Justice and Development Party), ultranationalist, and left unions. Left-wing unions started to get more involved in social movement unionism after the early 2000s. Firstly, as my interviewees pointed out, some of the student activists of the 1990s became union members and university faculty and took part in coordinating Eğitim-sen's activities (Kıvanç, 2014; Özcan, 2015).

Secondly, in 2007, Genç-Sen (Student Youth Union) was established under the blue-collar led DİSK's umbrella (Erdinç, 2013). Genç-Sen, organised protests against the proposed tuition fee increases in 2009 in Istanbul, Mersin, Ankara, Konya, Adana, and Eskişehir. In İstanbul, protests also included other DİSK members (Erdinç, 2013). The effect of Genç-Sen's protests was amplified by the protests that were organised by unaffiliated students through social media in 2009 (Ersin, 2015) as the protests organised by a newly established student movement organisation, the Student Collectives (sendika.org, 2009). This meant that both the blue-collar (DISK) and white-collar (Eğitim-Sen) trade unions supported student action, forging the alliance between the students and organised labour.

However, the youth union Genç-Sen did not adopt the role of student unions, which are centralised and organised in the major campuses in Germany. Instead, the trade unions themselves played a network formation role for the left-wing student groups by centralizing the focus for cooperation. DİSK and Eğitim-Sen's involvement in the protests, along with DİSK's initiative to establish Genç-Sen provided a critical 
institutional standing and resources for the leftist student groups, which helped them gain a voice in the media as well as in party politics. In response, the government reduced the tuition fee increased to $8 \%$, instead of the proposed $150 \%$ increase.

Student protests continued (see figure 2 below). They were often multi-issue protests that raised grievances not only about tuition fees but also about the Higher Education Council and government policies, especially the executive overreach. At Boğaziçi University in Istanbul, the students who protested the Prime Minister Recep Tayyip Erdoğan's visit were dispersed with tear gas (Hürriyet, 2010a). Police in Ankara stopped the student group's protests during Erdoğan's visit while some Genç-Sen members were detained (Hürriyet, 2010b). The next day, student groups organised a protest march in Kızılay, Ankara (Hürriyet, 2010c), as well as demonstrations in İstanbul and Izmir to protest against police violence (Hürriyet, 2010d). Small-scale protests continued throughout the year, but there was no indication of a tuition policy reversal.

- Figure 2 here-

In 2011, the social democrats endorsed free higher education in their electoral platforms for the first time. Tuition fees have always been a point of contention for student mobilisation in Turkey, which begs the question why did the social democrats decide to change their position this time. A former member of the parliament from the CHP (Republican People's Party), who had been very actively involved in the discussions on higher education policy, offered the following explanation:

It was also part of the attempt of CHP to reintroduce itself as a more leftist party after the administrative change in 2010-11.” (Serter, 2015) 
The first general election for the CHP, with its new leader, was in 2011. In the electoral platform, the CHP endorsed the slogan of "new CHP for everyone." Being inspired by the German social democrats' endorsement of supporting social movements, there was an attempt to drop "nationalist-secularist" perspectives and move closer to centre-left politics (Uysal, 2011). This indicated an opportunity for the social movements and the unions in Turkey to influence the main opposition party.

But why did the CHP picked tuition fees specifically? Firstly, student mobilisation on the eve of elections offered an appeal to a new constituency. Secondly, coordination meetings organised by Eğitim-Sen played a brokerage role. The growing number of protests in different cities prompted the Prime Minister Erdoğan to attempt to demonstrate that there was considerable student support for government policies. He announced a meeting with a select group of Student Council presidents in Erzurum in January 2011. The CHP leader Kemal Kılıçdaroğlu, however, organised a meeting with the Student Council presidents prior to Erdoğan's scheduled meeting (Hürriyet 2011a). An opposition faction had already emerged among the council presidents (23 student council presidents out of 152). It is that faction that met with Kılıçdaroğlu. After that meeting, Kılıçdaroğlu announced his opposition to tuition fees (Hürriyet2011b). With this announcement, the third link in the triadic relationship of movement mobilisation, organised labour, and the opposition party was finally established.

Despite the fact that the governing party (AKP) never promised free tuition fees during its campaign, the free-tuition announcement arrived after the elections in which the AKP lost 4 seats while the social democrats gained 33seats (Milliyet, 2012). This was a surprising turn of events given that unions that opposed tuition fees did not have any 
insider power, no meaningful access to the government, and the student protests remained multi-issue sporadic events. However, the coordination efforts of the unions and the potential of the students to offer a new constituency for the social democrats led to a freetuition endorsement from the main opposition party after three decades.

Nevertheless, free tuition fees did not put a stop to the student protests. The student collective action continued against the proposed changes to higher education legislation. The role of Eğitim-Sen in coordinating opposition can also be seen below, in the words of a Student Collectives activist:

On December $25^{\text {th }}$ [2012], all the youth organizations came together in response to Eğitim-sen's invitation for a meeting. We planned to organise collective action all over the country. It was about to start but we turned on the TV and METU [Middle East Technical University] was on fire. All of a sudden protests that initially targeted the Higher Education Legislation turned into anti-government protests in response to the police violence and partisan rectors (Özcan, 2015).

As the above quote suggests, by the end of 2012, leftist student activists' attention focused on police violence and the executive over reach, which was the main motivation for the Gezi Park protests of 2013. Nevertheless, the reversal of the tuition fee policy in Turkey shows how under unfavourable circumstances, an alliance between the organised labour and social movement groups might still influence centre-left parties on the eve of elections.

\section{Conclusion}

How effective are the alliances between trade unions and social movement organisations in influencing political party position on issues outside labour's purview? Potentially quite a bit. Tuition fee policy outcomes are a case in point. Students have a long history of protesting the introduction or increase of tuition fees. Their protests have become even more vocal in the wake of the Great Recession. Yet, only on very rare 
occasions have students been able to stop tuition fee increases by themselves. The success of the student mobilisation in Chile (Bellei, 2014) provides a stark contrast to the outcome of the student mobilisation in England, for example (Cini \& Guzman, 2017). However, over the past decade, opposition to tuition fee increases in public universities within advanced industrialised countries has forced centre-left parties to re-examine their policy choices (Türkoğlu, 2018). In this article, I argued that one of the key factors of the success of opposition has been an alliance between student movements and organised labour, which has attracted the support of social democratic parties.

I highlight the importance of analysing the triadic relationship between organised labour, student mobilisation, and centre-left parties as they formed an alliance against tuition fee increases. My case studies show that neither students, nor education unions were able to shift the opposition parties' commitments by themselves, but it was the alliance between the two that brought in the third corner of opposition, the social democrats. I compare student movement- organised labour alliances in Germany and Turkey, that is, in two radically different union structures and political contexts. In Germany, trade unions, the DGB and the GEW helped students sustain and increase pressure on the centre-left by employing electoral and legal tactics they previously developed. In Turkey, where the influence of leftist unions is far more limited, unions such as DİSK and Eğitim-Sen, nevertheless, helped coordinate student activism in the absence of nationally-organised student unions. Student mobilisation, on the other hand, signalled the centre-left a potential opportunity to broaden its base on the eve of elections. Thus, despite their differences, alliance building in Germany and Turkey features similarities in terms of its pooling of resources and its impact on centre-left 
parties in shifting their policy position and joining the opposition alliance. In Germany

and Turkey, respectively, the DGB and DİSK were mobilised for a non-labour issue and used their experience of organising labour to broker alliances and mount an effective opposition. This finding suggests that union density might be a poor measure of the political power unions have when they are engaged in social movement alliances. The case studies indicate that social movement - organised labour alliances may be effective in shifting social democratic politics in a variety of policy areas that are exposed to permanent austerity measures.

\section{References}

Ahlquist, J. S. (2010). Policy by contract: electoral cycles, parties and social pacts, 19742000. The Journal of Politics, 72(2), 572-587.

Almeida P (2006) Social movement unionism, social movement partyism, and policy outcomes: Health care privatization in El Salvador. Latin American Social Movements: Globalization, Democratization, and Transnational Networks, ed. Hank Johnston and Almeida. Lanham: Rowman and Littlefield: 57-73.

Amenta E, Caren N, and Olasky SJ (2005) Age for leisure? Political mediation and the impact of the pension movement on US old-age policy. American Sociological Review 70(3):516-538.

Amenta E, Elliott TA, Shortt N, Tierney A, Türkoğlu D, Vann B. (2017) From bias to coverage: What explains how news organizations treat social movements. Sociology Compass 11(3).

Anderson KM and Meyer T (2003) Social democracy, unions, and pension politics in Germany and Sweden. Journal of Public Policy 23(1): 23-54.

Baccaro L, Hamann K and Turner L (2003) The politics of labour movement revitalization: The need for a revitalized perspective. European Journal of Industrial Relations 9(1): 119-133.

Beamish, T. D., \& Luebbers, A. J. (2009). Alliance building across social movements: Bridging difference in a peace and justice coalition. Social Problems, 56(4), 647676. 
Behrensm M, Fichter M \& Frege C M. (2003) Unions in Germany: Regaining the Initiative? European Journal of Industrial Relations. 9(1): 25-42.

Bellei C, Cabalin C and Orellana V (2014) The 2011 Chilean student movement against neoliberal educational policies. Studies in Higher Education 39(3): 426-440.

Blee, K. M., \& Currier, A. (2006). How local social movement groups handle a presidential election. Qualitative Sociology, 29(3), 261.

CHP (2011) Election Manifesto. Cumhuriyet Halk Partisi.

Cini L and Guzmán-Concha C (2017) Student movements in the age of austerity. The cases of Chile and England. Social Movement Studies 16(5): 623-628.

Clawson D (2008) Neo-liberalism guarantees social movement unionism. Employee Responsibilities and Rights Journal 20(3): 207-212.

Connolly, H., \& Darlington, R. (2012). Radical political unionism in France and Britain: A comparative study of SUD-Rail and the RMT. European Journal of Industrial Relations, 18(3), 235-250.

Crossley, N., \& Ibrahim, J. (2012). Critical mass, social networks and collective action: Exploring student political worlds. Sociology, 46(4), 596-612.

Cumhuriyet (1995a) Öğrenciler meclisten yanıt bekliyor. 22 November.

Cumhuriyet (1995b) Üniversitede gerginlik bitmiyor. 19 December.

Cumhuriyet (1996a) Harç eylemi büyüyor. 1 March.

Cumhuriyet (1996b) Öğrencilerin harç eylemine destek.7 February.

Cumhuriyet (1996c) Memuru duymayan bir meclis kald1. 14 April.

Culpepper P D and Regan A (2014) Why don't governments need trade unions any more? The death of social pacts in Ireland and Italy. Socio-Economic Review 12(4): 723-745.

Çelik, A. (2013). Trade unions and deunionization during ten years of AKP rule. Perspective-Political analysis and commentary from Turkey, 3(2013), 44-48.

Diani, M. (2018). Unions as social movements or unions in social movements? 1. In Social Movements and Organized Labour (pp. 43-65). Routledge. 
Dixon M, Danaher W \& Kail B. (2013) Allies, Targets, and the Effectiveness of Coalition Protest: A Comparative Analysis of Labor Unrest in the U. S. South. Mobilization : An International Quarterly 18(3): 331-350.

Dixon M and Martin AW (2012) We can't win this on our own: Unions, firms, and mobilization of external allies in labor disputes. American Sociological Review 77(6): 946-969.

Doğan, M G (2018). Türkiye'de sendikal hareket üzerine (Y D Çetinkaya, Ed.). In Toplumsal Hareketler: Tarih, teori ve deneyim. İstanbul: Iletişim.

Dörre, K., Holst, H., \& Nachtwey, O. (2009). Organising-A strategic option for trade union renewal?. International Journal of Action Research, 5(1), 33-67.

Durazzi N, Fleckenstein T \& Lee S C (2018) Social Solidarity for all? Trade Union Strategies, Labor Market Dualization, and the Welfare state in Italy and South Korea. Politics \& Society

Eğitim-sen (2018) Eğitim-sen'in 23. mücadele yılı kutlu olsun, 23 January 2018. http://egitimsen.org.tr/egitim-senin-23-mucadele-yili-kutlu-olsun/

Erdinç I (2013) Trade Union Strategies and Legacy of the 1960s in Student Mobilization in Turkey: The Case of the Student Youth Union Öğrenci Gençlik Sendikası (Genç-Sen). European Journal of Turkish Studies.17.

Ersin (2015) Interview in İstanbul.

FAZ (2006a) DGB: Vermögenssteuer statt Studiengebühren, 14 June.

FAZ (2006b) Tausende demonstrieren gegen Bildungspolitik/ Auseinandersetzungen mit der Polizei, 29 June.

FAZ (2006c) Studenten plannen "protestherbst" Zummanarbeit mit DGB, 23 September.

FAZ (2006d) Tausende bei DGB-Sternmarch, 23 October.

FAZ (2006e) Stadtverordnetenversammlung: Grüne enthalten sich bei Antrag gegen Studiengebühren, 3 June.

FAZ (2006f) Jusos: SPD in Hessen derzeit chancenlos, 20 May.

FAZ (2007a) Studiengebühren werden von Verfassungsgereicht überprüft, 15 February.

FAZ (2007b) Erst Boykottbeschluss, dann Protestmarsch, 11 May.

FAZ (2007c) Studiengebühren: 1000 Unterschriften fehlen, 22 May. 
FAZ (2007d) Zweite Klage gegen Studiengebühren, 62500 Unterschriften gesammelt, 1 June.

FAZ (2008a) 'Land zweifelt Volksklage an', Studiengebühren: Streit um Unterschriften, 23 January.

FAZ (2008b) GEW kritisiert hessische Hochschulpolitik", 25 January.

FAZ (2008c) Keine Studiengebühren mehr, 16 November.

Gamson WA (2004) Bystanders, public opinion, and the media. The Blackwell companion to social movements: 242-261.

Giroux HA (2013) The Quebec student protest movement in the age of neoliberal terror. Social Identities 19(5): 515-535.

Gordon, A., \& Upchurch, M. (2012). Railing against neoliberalism: Radical political unionism in SUD-Rail and RMT. European Journal of Industrial Relations, $18(3), 259-265$.

Greer I (2008) Social movement unionism and social partnership in Germany: the case of Hamburg's hospitals. Industrial Relations: A Journal of Economy and Society 47(4): 602-624.

Grote, J. R., \& Wagemann, C. (2018). Passions, interests and the need to survive. In Social Movements and Organized Labour (pp. 1-21). Routledge.

Heery, E., Williams, S. and Abbott, B., 2012. Civil society organizations and trade unions: cooperation, conflict, indifference. Work, Employment and Society, 26(1), pp.145-160.

Hess DJ (2014) Sustainability transitions: A political coalition perspective. Research Policy 43(2): 278-283.

Huber, E., Ragin, C., \& Stephens, J. D. (1993). Social democracy, Christian democracy, constitutional structure, and the welfare state. American journal of Sociology, 99(3), 711-749.

Hürriyet (2003) Yök'ü protesto eyleminde olay çıktı. 6 November.

Hürriyet (2005) Beyazıt'ta YÖK karşıtı eylemler. 9 November.

Hürriyet (2010a) Boğaziçi Üniversitesinde arbede. 5 November.

Hürriyet (2010b) Dayağı yediler serbest kaldılar. 6 December.

Hürriyet (2010c) Pasaport da sorsaydınız. 5 December.

Hürriyet (2010d) Terörü polis estirdi. 6 December. 
Hürriyet (2011a) Kılıçdaroğlu öğrencilerle buluştu. 24 January.

Hürriyet (2011b) İktidar Tunus'un diplomalı işsiz devrimini izlesin. 25 January.

Hürriyet (2011) Saadet Partililerden üniversite harçlarına protesto. 25 February.

Hürriyet (2013) Üniversitelerde YÖK protestosu. 6 November.

Ibrahim J (2011) The new toll on higher education and the UK student revolts of 20102011. Social Movement Studies 10(4): 415-421.

Jan (2014) Interview in Frankfurt.

Johnston P (1994) Success while others fail: Social movement unionism and the public workplace. Cornell University Press.

Kıvanç (2014) Interview in Ankara.

Korpi, W., \& Shalev, M. (1980). Strikes, power, and politics in the Western nations, 1900-1976.

Keller A (2002) Aktuelle Trends und alternative Perspektiven der Hochschulentwicklung. WSI Mitteilungen.-2007. 60: 281-284.

Klaus (2016) Interview in Cologne.

Krinsky, J., \& Crossley, N. (2014). Social movements and social networks: Introduction. Social Movement Studies, 13(1), 1-21.

Lange M (2012) Comparative-historical methods. Sage.

Larreguy, H., Montiel Olea, C. E., \& Querubin, P. (2017). Political Brokers: Partisans or Agents? Evidence from the Mexican Teachers' Union. American Journal of Political Science, 61(4), 877-891.

Lee J (2011) Insularity or Solidarity? The Impacts of Political Opportunity Structure and Social Movement Sector on Alliance Formation. Mobilization: An International Quarterly 16(3):303-324.

Loschi C (2018) Local mobilizations and the formation of environmental networks in a democratizing Tunisia. Social Movement Studies: 1-20.

McAdam D and Tarrow S (2010) Ballots and barricades: On the reciprocal relationship between elections and social movements. Perspectives on Politics 8(2): 529-542. 
McCammon H and Campbell K (2002) Allies on the road to victory: Coalition formation between the suffragists and the Woman's Christian Temperance Union. Mobilization: An International Quarterly 7(3): 231-251.

McCammon H and Minyoung M 2(015) Social Movement Coalitions. in The Oxford Handbook of Social Movements, Oxford University Press.

McCarthy MA (2012) Occupying higher education: The revival of the student movement. In: New Labor Forum, Sage Publications Sage CA: Los Angeles, CA, pp. 50-55.

Milliyet (2012) Üniversite harçları kaldırıldı. 28, August.

Neyzi, L. (2001). Object or subject? The paradox of "youth" in Turkey. International Journal of Middle East Studies, 33(3), 411-432.

Nicklich, M., \& Helfen, M. (2018). Trade union renewal and 'organizing from below'in Germany: Institutional constraints, strategic dilemmas and organizational tensions. European Journal of Industrial Relations, 0959680117752000.

Obach BK (2004) Labor and the environmental movement: The quest for common ground. MIT press.

Obach, B. (2010). Political opportunity and social movement coalitions: The role of policy segmentation and nonprofit tax law. Strategic Alliances: Coalition Building and Social Movements, 197-218.

Özcan (2015) Interview in İstanbul.

Özden, B. A., Akça, İ., \& Bekmen, A. (2017). Antinomies of authoritarian neoliberalism in Turkey: The Justice and Development Party era. States of discipline: Authoritarian neoliberalism and the contested reproduction of capitalist order, 189-210.

Pontusson, J., \& Rueda, D. (2010). The politics of inequality: Voter mobilization and left parties in advanced industrial states. Comparative Political Studies, 43(6), 675705.

Reese E, Petit C and Meyer DS (2010) Sudden mobilization: movement crossovers, threats, and the surprising rise of the US antiwar movement. Strategic Alliances: Coalition Building and Social Movements: 266-91.

Reyes DV (2015) Inhabiting Latino Politics: How Colleges Shape Students' Political Styles. Sociology of Education 88(4): 302-319.

Rose F (2000) Coalitions across the Class Divide: Lessons from the Labor, Peace, and Environmental Movements. Cornell University Press. 
Sendika.org (2009) Harçlara karşı üniversiteliler tüm Türkiye'de harekete geçiyor. 21, July.

Serter (2015) Interview in Ankara.

Smeltzer S and Hearn A (2015) Student rights in an age of austerity? 'Security', freedom of expression and the neoliberal university. Social Movement Studies 14(3): 352358.

Tarrow, S. G. (2011). Power in movement: Social movements and contentious politics. Cambridge University Press.

Tattersall, A. (2013). Power in coalition: Strategies for strong unions and social change. Cornell University Press.

Turner, L and Hurd R (2001). Building social movement unionism. Rekindling the movement: Labor's quest for relevance in the twenty-first century: 9-26.

Turner, L. (2009). Institutions and activism: crisis and opportunity for a German labor movement in decline. Industrial and Labor Relations Review 62(3): 294-312.

Türkoğlu, D. (2018). As Tuition Rises: Opposition to Neoliberalization of Higher Education. American Sociological Association Annual Meeting, Philadelphia, USA.

Uysal, A. (2011) Continuity and rupture: The "new CHP" or "What has changed in the CHP?". Insight Turkey 13(4): 129-146.

Upchurch, M., \& Taylor, G. (2016). The crisis of social democratic trade unionism in Western Europe: The search for alternatives. Routledge.

Üzüm, T. (2011). KESK tarihi: kamu çallşanlarının sendikal mücadele süreci. Kalkedon yayınları.

Van Dyke N (2003) Crossing movement boundaries: Factors that facilitate coalition protest by American college students, 1930-1990. Social Problems 50:226-250.

Van Dyke N and Carlon (2007) Manufacturing Dissent: Labor Revitalization, Union Summer, Student Protest. Social Forces.

Vicari S (2014) Networks of Contention: The Shape of Online Transnationalism in Early Twenty First Century Social Movement Coalitions. Social Movement Studies 13(1): 92-109.

Voss K and Sherman R (2000) Breaking the iron law of oligarchy: Union revitalization in the American labor movement. American Journal of Sociology 106(2): 303-349. 
Walker ET (2009) Privatizing participation: Civic change and the organizational dynamics of grassroots lobbying firms. American Sociological Review 74(1): 83105.

Welsh HA (2009) Higher Education Reform in Germany: Advocacy and Discourse. German Politics \& Society 27(1): 1-23.

Wilson BR and Curnow J (2013) Solidarity ${ }^{\mathrm{TM}}$ : Student activism, affective labor, and the fair trade campaign in the United States. Antipode 45(3): 565-583.

Zajak S (2013) A Political Economic View of Social Movements: New Perspectives and Open Questions. Moving the Social 50: 121-142.

Zajak, S., Gortanutti, G., Lauber, J., \& Nikolas, A. M. (2018). Talking about the same but different? Understanding social movement and trade union cooperation through social movement and industrial relations theories. Industrielle Beziehungen, 2.

Zamponi L and Fernández González J (2017) Dissenting youth: how student and youth struggles helped shape anti-austerity mobilisations in Southern Europe. Social Movement Studies 16(1): 64-81. 


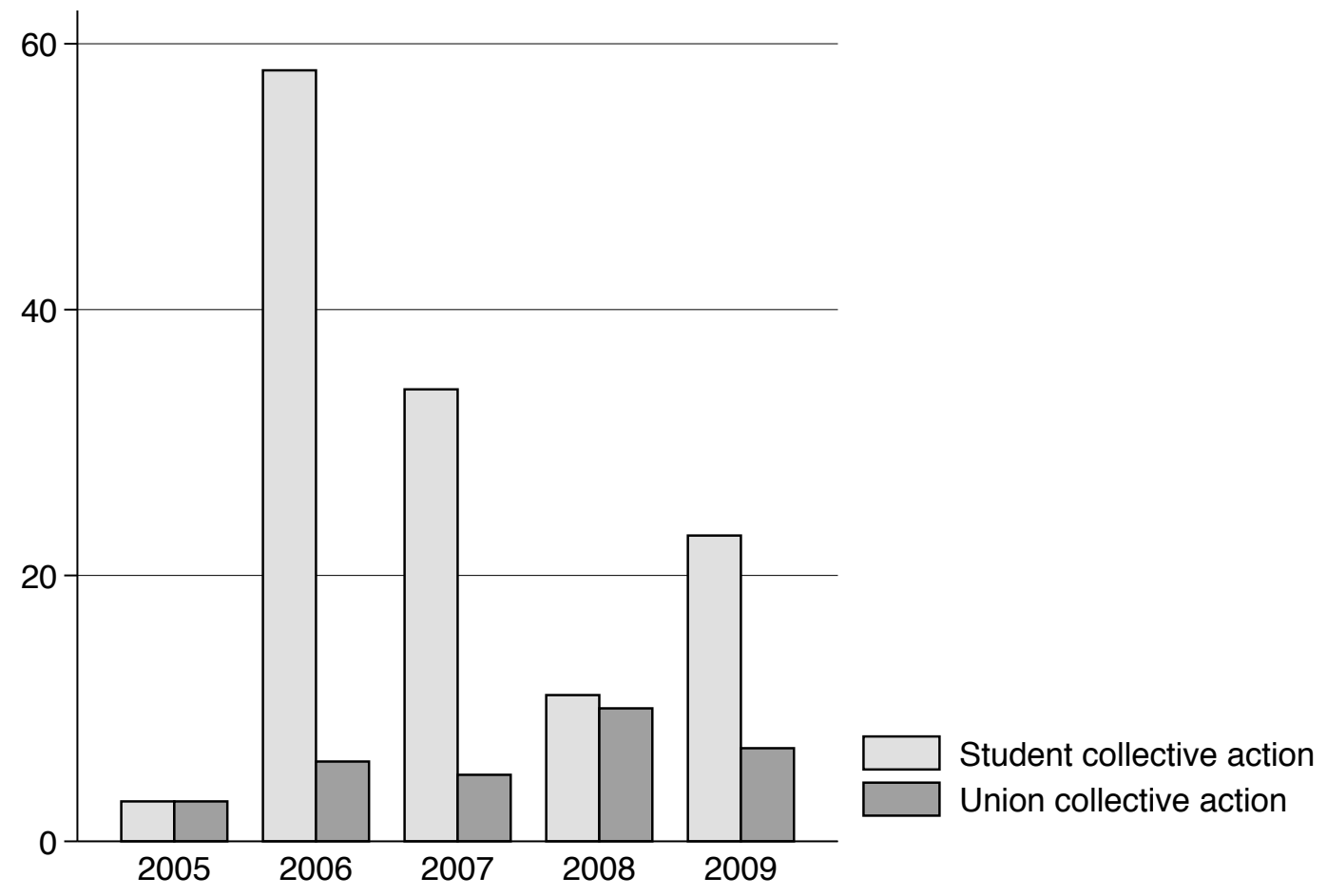

Figure 1. Number of news articles on tuition fees that report student and union collective action 


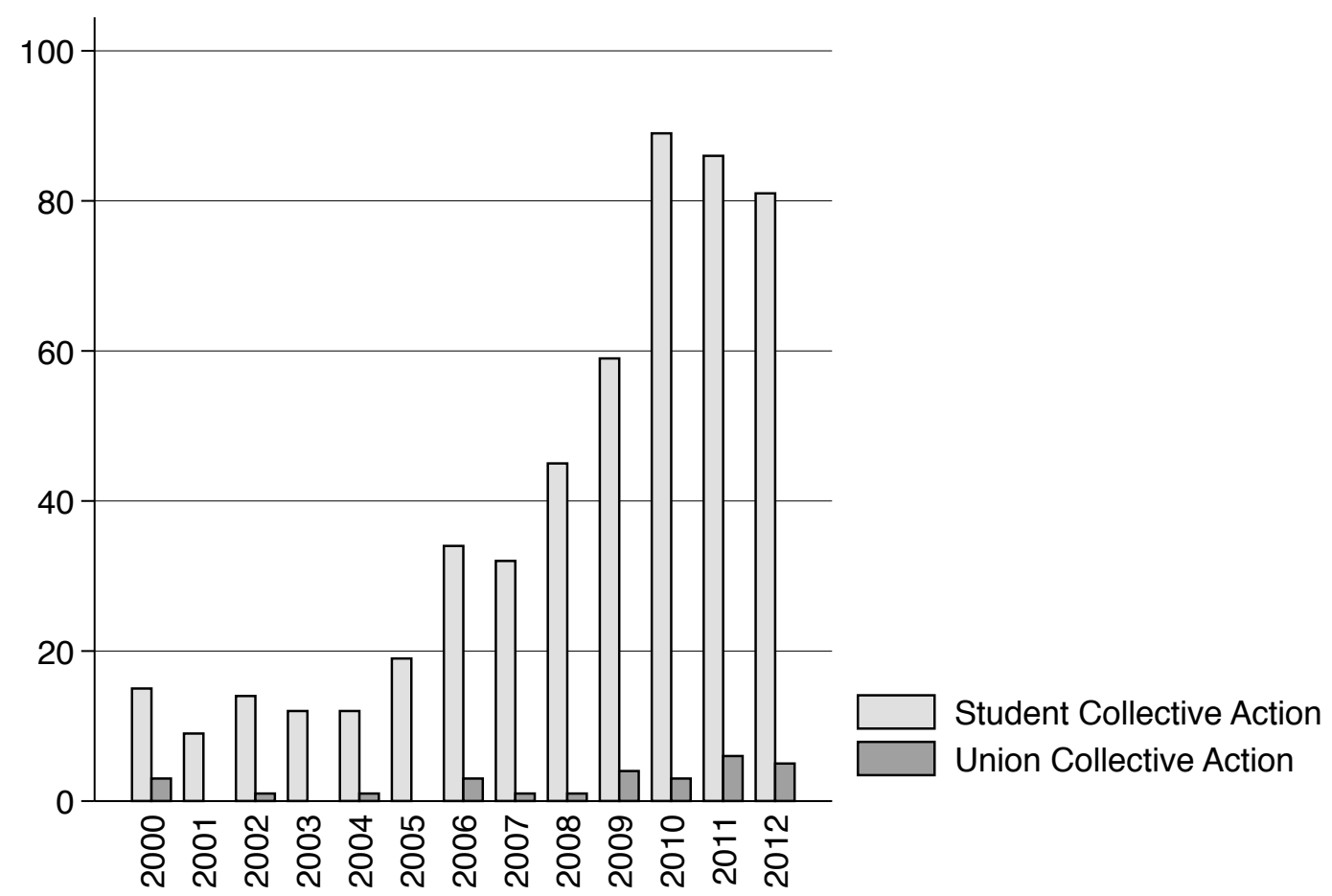

Figure 2. Number of articles in Hürriyet on student collective action and union participation in student protests 
Table 1. Introduction and abolition of tuition fees by state and party in power

\begin{tabular}{|l|l|l|l|l|}
\hline & \multicolumn{2}{|l|}{ Introduction } & Abolition \\
\hline & Law Passed & Government & Law Passed & Government \\
\hline $\begin{array}{l}\text { Baden - } \\
\text { Württemberg }\end{array}$ & $12 / 15 / 2005$ & CDU - FDP & $12 / 21 / 2011$ & $\begin{array}{l}\text { Greens - } \\
\text { SPD }\end{array}$ \\
\hline Bavaria & $5 / 18 / 2006$ & CSU & $2 / 23 / 2013$ & FDP-CSU \\
\hline Hamburg & $6 / 28 / 2006$ & CDU & $12 / 15 / 2011$ & SPD \\
\hline Hesse & $\mathbf{1 0 / 5 / 2 0 0 6}$ & CDU & $\mathbf{6 / 1 7 / 2 0 0 8}$ & CDU \\
\hline $\begin{array}{l}\text { Lower } \\
\text { Saxony }\end{array}$ & $12 / 9 / 2005$ & CDU - FDP & $12 / 10 / 2013$ & CDU-FDP \\
\hline $\begin{array}{l}\text { North Rhine- } \\
\text { Westphalia }\end{array}$ & $3 / 16 / 2006$ & CDU - FDP & $2 / 24 / 2011$ & $\begin{array}{l}\text { SPD - } \\
\text { Greens }\end{array}$ \\
\hline $\begin{array}{l}\text { Saarland } \\
\text { CDan-FDP- } \\
\text { Greens }\end{array}$ \\
\hline
\end{tabular}

Table 2. Interviews

\begin{tabular}{|l|l|c|}
\hline Country & Position of Interviewees & Number of Interviews \\
\hline \multirow{5}{*}{ Germany } & Student Activist & 12 \\
& Union Member & 3 \\
& Faculty & 2 \\
\hline \multirow{5}{*}{ Turkey } & Student Activist (in 1990s) & 4 \\
& Student Activist (in 2000s) & 14 \\
& Member of Parliament (MP) & 3 \\
& Political Advisor to MP & 2 \\
& Union Members & 5 \\
& Faculty & 2 \\
\hline Total & Bureaucrat & $\mathbf{5 1}$ \\
\hline
\end{tabular}

